\title{
Decision support system for economic value of irrigation water
}

\author{
Inas El-Gafy • Akram El-Ganzori
}

Received: 3 October 2011/Accepted: 2 February 2012/Published online: 11 April 2012

(C) The Author(s) 2012. This article is published with open access at Springerlink.com

\begin{abstract}
The mismatch between the supply and demand, inequitable distribution and the over irrigation of water consuming crops are the main constraints that are faced in the implementation of the integrated water resources management in Egypt. With water scarcity, the problem under consideration is that the current cropping pattern is not economically efficient in the utilization of the available water resource. Moreover, in consequence of the importance of the agricultural sector to the national economies, it is necessary to be aware of the economic performance of water use in the crops production. The scope of this study is to develop economic value of irrigation water maps of Egypt. The objective of the study is carried out by acquiring a Decision Support System for economic value of irrigation water of Egypt. This Decision Support System is applied for developing economic value maps for the irrigation water that is used for cultivating 45 crops under cereal, fiber, legumes, and vegetables, herbalist, and forages categories at each governorate of Egypt in year 2008 and 2009. The crops that achieve the highest and lowest economic value of irrigation water at each governorate of Egypt were identified. The reasons of the variations in the economic value of irrigation water at the governorates of Egypt were determined. The developed Decision Support System could be used yearly as a tool for demonstrating a picture about the economic value of irrigation water for the decision makers in the areas of water resources and agriculture. The developed economic value of irrigation water maps can be used in proposing a cropping pattern that maximizes the
\end{abstract}

I. El-Gafy $(\bowtie) \cdot$ A. El-Ganzori

Strategic Research Unit,

National Water Research Center, Cairo, Egypt

e-mail: inaa_2r@yahoo.com

A. El-Ganzori

e-mail: Elganzori@hotmail.com economic value of irrigation water in each governorate of Egypt.

Keywords Economic value of irrigation water - Decision Support System · Cropping pattern · Maps · Integrated water resources

\section{Introduction and objective}

Increasing demand for food, feed, fuel, and fiber will require increasing efficiency from agricultural production systems. In the water resources and agricultural sector, return per unit of investment is a measure of efficiency (Hatfield 2011). In the crop production area, decision-making process is considered limited when contemplated only the performance evaluation of crop yield. Using an efficiency-based approach, fields will not be evaluated only on their yield but also on their return per unit input of water, nutrients, or energy, as well as the impact of improved genetics and management practices.

The economic value of water depends on the user as well as on the use to which it is allocated. The value of water should reflect the economic, environmental, cultural and religious values of the society El-Atfy and Kotb (2004). Information on water's economic value enables decision makers to make informed choices on water development, conservation, allocation, and use when growing demands for all uses are made in the face of increased scarcity. Conceptually correct and empirically accurate estimates of the economic value of water are essential for rational allocation of scarce water across locations, uses, users, and time periods (Warda and Michelsen 2002).

In Egypt, population growth and the horizontal expansion plans of the government increase the demand for irrigation water. A considerable increase in efficiency is 
required to make this additional required water available. Such an efficiency improvement will have important social as well as economic impacts, e.g. when changes in the cropping pattern are required (shift from crops with a high water demand to less sensitive crops (MWRI 2005). The Egyptian cropping pattern was mainly controlled by Egyptian government for a long period (1961-1986). Several studies, revealed the deviation of the prevailing cropping pattern from optimal one that could achieve economic efficiency in allocating resources and increasing agricultural production (Negm et al. 2006; Kuo 2001). Starting from 1987, an agricultural liberalization policy was implemented in Egypt. Some studies indicated just slight improvement toward achieving economic efficiency as a result of the changes that occurred in the cropping pattern after the liberalization policy (Negm et al. 2006). With water scarcity, the problem under consideration is that the current cropping pattern is not economically efficient in the utilization of the available water resource. Therefore, the target of the agriculture and water resources policy of Egypt ought to maximize economic efficiency of the available water resources, taking into consideration the freedom of the farmer in choosing the crops to plant.

Some studies were carried out considering the economic value of irrigation water and cropping pattern of Egypt. Shahata and Raghab (2008) recommended a cropping pattern at the national level that achieve the optimal economic use of water resources, Negm et al. (2006) investigate two scenarios for the cropping pattern at the national level. The first scenario is associated with the continuation of the local prices of crops; while the second one is associated with the dynamic global conditions, this study concludes with the necessity to modify the current cropping pattern in Egypt in order to achieve the efficient utilization of water resources available, Salah (2002) recommended a cropping pattern that achieve an increase in both the net revenue from some plants and return unit of irrigation water at the national level, El-Atfy and Kotb (2004) illustrate the national economic value of nine main crops that are wheat, beans, sugar beet, clover, flax, rice, maize, sugar cane, and cotton, Shahata (1993) recommend that it is essential to reconsider the cropping pattern in the light of the economic efficiency of water use. The previous are carried out at the national level or consider some crops at some governorates of Egypt. None of these studies consider most of the crops at all the governorates of Egypt simultaneously.

The main objective of the current study is formulated to help in the future water management of Egypt by developing a decision support system for calculating and producing irrigation water economic value maps for different crops all over Egypt. These maps could be used as a tool for evaluating the economic performance of water use in the crop production and help in proposing a new cropping pattern toward maximizing the economic value of irrigation water. The study approach consists of five stages: (1) develop a Decision Support System for Economic Value of Irrigation Water (DSS-EVIW); Microsoft Access and ArcMap 9.3 are applied to develop DSS-EVIM, (2) apply the developed DSS-EVIW in calculating and develop irrigation water economic value maps for 45 crops; the most essential crops in Egypt, (3) analyse the developed economic value maps, (4) identify the highest and lowest irrigation water economic value crops at each governorate of Egypt, and (5) illustrate the variation of the economic value of irrigation water in different regions of Egypt (lower, middle and upper Egypt).

\section{The Egyptian physiography and climate}

Egypt is divided into three main agro-climatic zones, as shown in Fig. 1: (1) lower Egypt (Nile Delta), extending from the north of Cairo to the Mediterranean Sea and is characterized by some winter precipitation, (2) middle Egypt, extending from Cairo south to the boundary of Minia/Assuit governorates and characterized by minimal rainfall, and (3) upper Egypt, extending southwards from the Minia/Assuit governorates boundary to the Sudanese border and characterized by the almost complete absence of rainfall. The desert governorates did not considered through the study due their own characteristic (the cropping pattern in these governorates is determined for purposes of research or reclamation).

\section{Egyptian water resources and agriculture}

\section{Water resources in Egypt}

Egypt receives more than $95 \%$ of its freshwater resources from the Nile River. Water resources in Egypt are divided into conventional water resources and non-conventional water resources. In year 2008/2009, the quantity of conventional water resources and non-conventional water resources was $74.2 \mathrm{BCM} /$ year. The water resources in Egypt in year 2008-2009 were: Nile River (55.5 BCM/year); representing $76.7 \%$ of Egypt's water resources, underground water (6.2 BCM/year); representing 8.6\% of Egypt's water resources, rains and floods (1.3 BCM/year); representing 1.8\% of Egypt's water resources, drainage water reuse $(8.0 \mathrm{BCM} /$ year $)$; representing $11.1 \%$ of Egypt's water resources, and sewage water recycling (1.3 BCM/year); representing 1.8\% of Egypt's water resources, and water desalination $(0.06 \mathrm{BCM} /$ year $)$; representing $0.1 \%$ of Egypt's water resources (CAPMAS 2010).

\section{Agriculture in Egypt}

The total area of irrigated land in year 2009 was approximately 8.7 million feddans (feddan $=4,220 \mathrm{~m}^{2}$ ) and 
Fig. 1 Main agro-climatic zones of Egypt

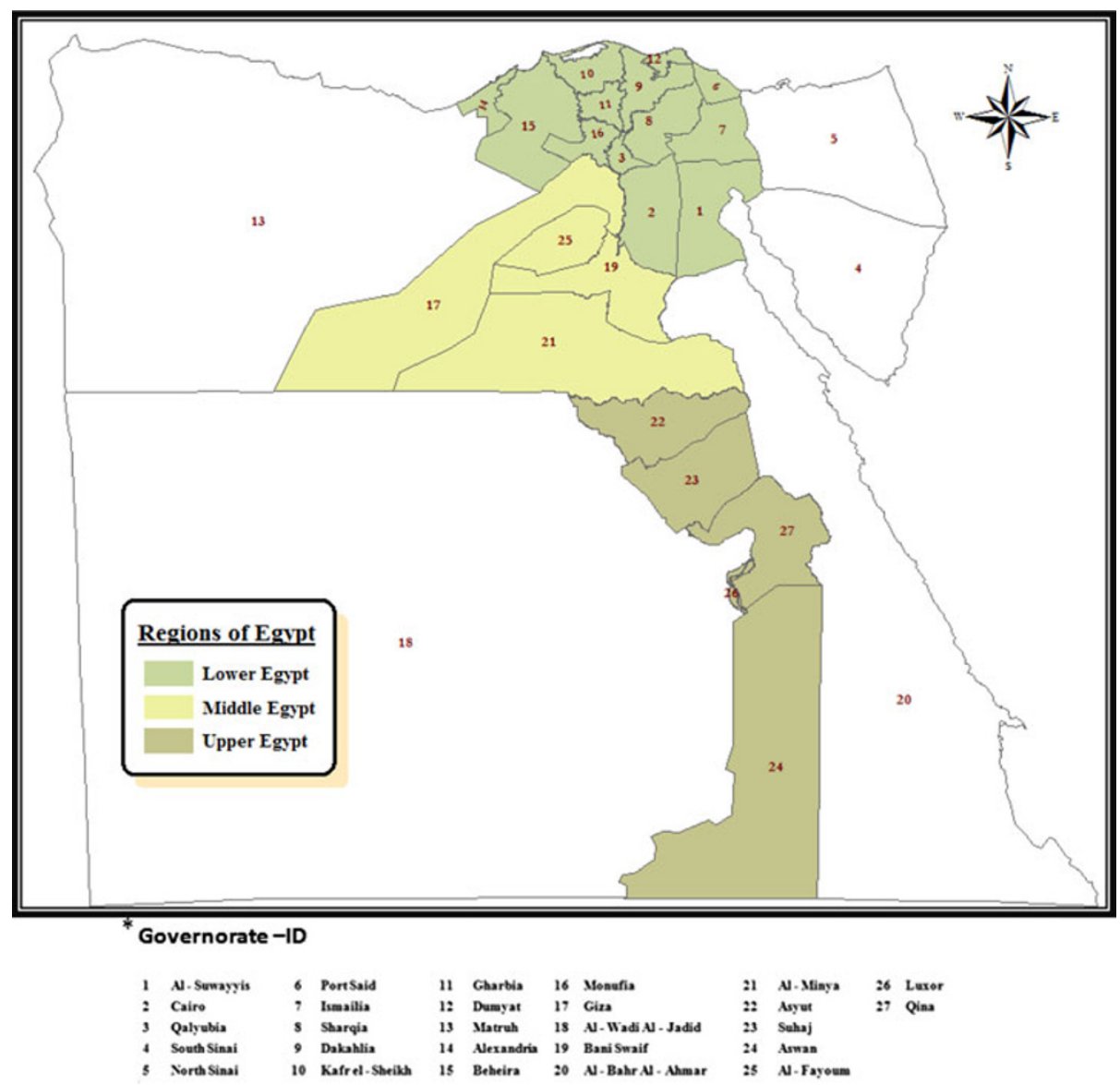

expected to reach 11 million feddans by the year 2017 after the implementation of the horizontal expansion plan and the national mega projects (Attia 2009). The agricultural sector represents $13.22 \%$ of the GDP year 2008. It provides employment for about $34 \%$ of the Egyptian labor force and plays an important role for the public in sustenance farming. The cultivated crops are many in Egypt. The important crop varieties are cereals (rice, wheat and maize), fiber (cotton has traditionally been the most important fiber crop in Egypt), sugar crops (sugar cane is the main sugar crop in upper Egypt and sugar beet also grows in large areas in the lower Egypt), legumes (include a number of bean crops such as broad beans and soybeans), forage crops (Egyptian long clover is the major forage crop), vegetables and fruits.

The main features of the water and agricultural policy of Egypt

The recent versions of the water policy of Egypt up to 2017 and 2030 call for the improvement of the economic efficiency of water use (MWRI 2005; MWRI 2010), by shifting the cropping pattern to save water, achieving better integration between agricultural and water resource policies, and maximizing the economic and social return from water resources. Also the agriculture strategy to 2030 emphasis the rationalization of irrigation water use through adopting several measures such as the adjustment of the cropping pattern that considers the revenues per unit of water (Siam and Moussa 2003; MALR 2005; MALR 2009).

\section{Methodology}

To achieve the objective of the current study, a number of activities are carried out. The DSS-EVIW (Decision Support System for Economic Value of Irrigation Water) was implemented to compute and develop the economic value of irrigation water maps. Then, the collection of necessary data on the cost, revenue, consumed water and the cultivated area of the important crops in Egypt is accomplished. The applications of DSS-EVIW that calculate and develop irrigation water economic value maps for 45 crops, the most essential crops in Egypt, were analyzed.

\section{Development of DSS-EVIM}

DSS-EVIW contains three main components, namely, database, model and user interface subsystem. Figure 2 schematics the frame work of the developed DSS-EVIW. The function of the database subsystem is to store and 
manipulate the spatial and temporal data. The model subsystem is operated to calculate the economic value of the irrigation water. The user interface subsystem is designed to facilitate the use of the DSS either by expert or non-expert user. In all cases, the subsystems are designed in a simple approach to avoid the need for sophisticated background or training requirements. Microsoft Access and ArcMap 9.3 represent the main programs that used to develop DSS-EVIM.

Model base sub-system

There are several methods for estimating the value of water. Agudelo (2001) provides a comprehensive overview of the most relevant methods generally applied to assess the value of water in its different uses. Agudelo (2001) grouped these methods into three main categories: (1) the methods that infer values from information regarding markets of water or waterrelated benefits; (2) the methods that infer values from the derived demand for water, where water is taken as an intermediate good for instance in the cases of irrigation of crops, cooling, processing or manufacturing operations, or driving of turbines to generate electricity; and (3) the methods that infer values from a direct consumer demand, in cases where water is considered a final (consumption) good. The current study considers water as an intermediate good. The applicable methods for determining economic value of water as intermediate good are willing to pay for water, production function method, residual valuation method, and value-added method (Yokwe 2005; Ashfaq et al. 2005; Agudelo 2001).

In the Egyptian case study, farmers are not paying for irrigation water as it is provided by the government for free (Abu-Zeid 2001). Moreover, there is no measurement of the actual water consumption on the farm level. Consequently, it is not possible to establish a relationship between price and demand from actual behavior to generate demand functions for water use and it is difficult to know the marginal value of water. Besides, according to Agudelo (2001) if there are inputs which are un-priced, not competitively priced or not employed to the point where their price equals their value of marginal product, then the residual imputation method will generate inaccurate estimates of water values. Therefore, it is difficult to apply methods such as willing to pay, production function methods, and the residual valuation method for estimating the economic value of irrigation water in Egypt.

The value-added method is an approach particularly well suited to estimating benefits in production sectors, where water is an intermediate good. Value added generally refers to net payments to primary resources (the costs of preparation of the agricultural land, seeds, irrigation, fertilization, agricultural service, pests' resistance, and harvest, transportation of the crop, and public expenditures). The disadvantage of the value-added method is that the use of the regional value-added criterion leads in some cases to attributing the productivity of all primary resources (labor, capital, other natural resources, etc.) to the value of water. However, value added is often measured on a sector-by-sector basis through an input-output model representing the structure of the economy of a region (Agudelo 2001). The value-added concept could be functional in planning an economically efficient allocation of water between different crops in the agricultural sector. Therefore, the economic value of irrigation water through the study is computed applying value-added method using Eq. 1:

$\mathrm{NR}_{i j}=\left(\mathrm{TR}_{i j}-\left(P_{i j} \times Q_{i j}\right)\right) / W_{i j}$
Fig. 2 Frame work of the developed DSS-EVIW

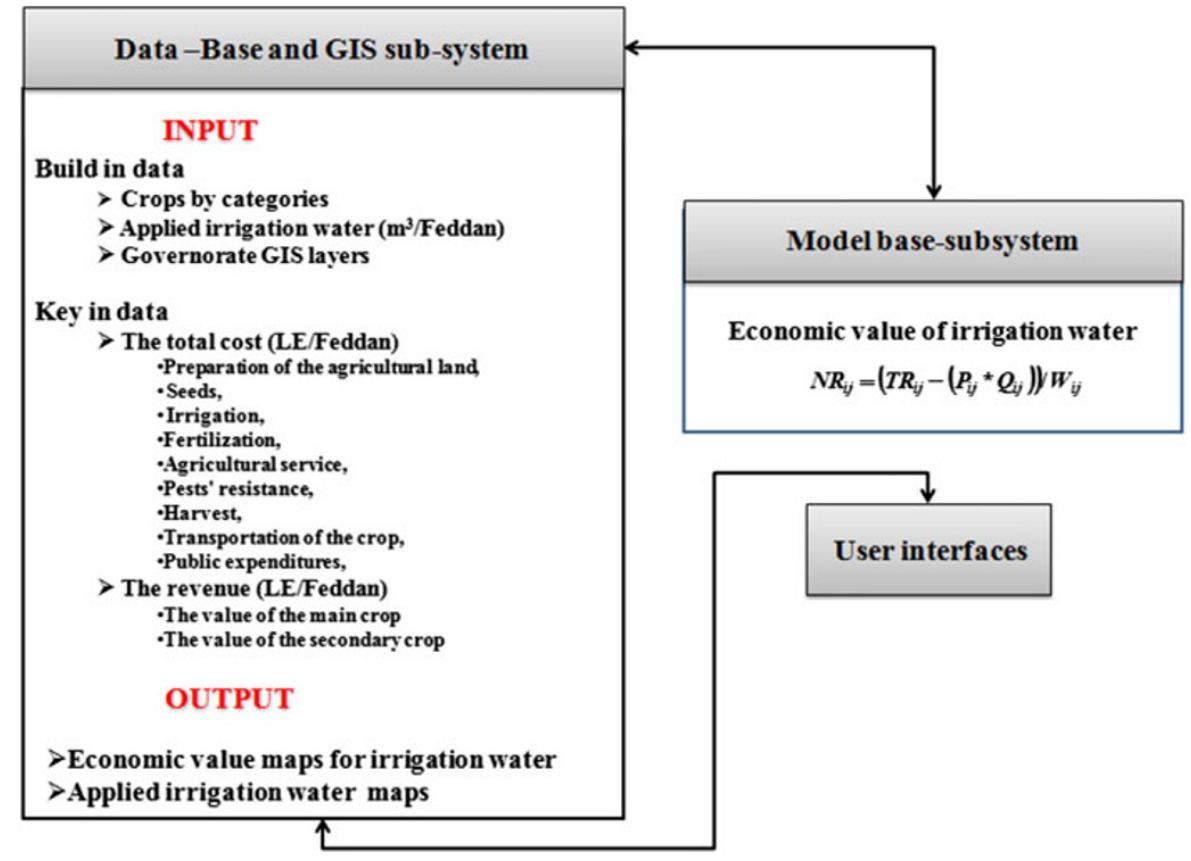


$\mathrm{NR}_{i j}$ is the net return per unit of water from cultivating crop (i) at governorate $(j)\left(\mathrm{LE} / \mathrm{m}^{3}\right), \mathrm{TR}_{i j}$ is total revenue per feddan from crop $(i)$ at governorate $(j)$ (LE/feddan), $\mathrm{P}_{i j}$ and $\mathrm{Q}_{i j}$ are the costs and quantities of the inputs used per feddan for cultivating crop (i) at governorate ( $j$ ) (LE/feddan), and $\mathrm{W}_{i j}$ is the quantity of water applied per feddan for crop (i) at governorate $(j)\left(\mathrm{m}^{3} /\right.$ feddan).

\section{Database subsystem}

The main purpose of the developed database is to store and tabulate the data, compute the economic value maps, and link the input data and the output of running the model with the developed Geographic Information System. The designed database could be expanded for more data in the future. In addition, it has an easy-to-use graphical user interface. To fulfill all the objectives of the database, different forms, queries and macros are developed to view, edit, modify the data, compute the economic value of irrigation, and connect the input data and the output of running the model with the developed Geographic Information System.

As shown in Fig. 1, the main input data and information for the DSS-EVIW are divided into two main forms that are the built in data and the key in data. The built in data includes the different crops by categories and their cultivated season and the water applied per feddan for each crop at lower, upper, and middle Egypt. The key in data includes information about the costs and revenues of crop production per feddan. The costs data include the costs of preparation of the agricultural land, seeds, irrigation, fertilization, agricultural service, pests' resistance, and harvest, transportation of the crop, and public expenditures. The output from the DSS-EVIW are the total cost and total net return (LE) of cultivating each crop and economic value maps for irrigation water that is used in the crops production all over the country.

\section{User interface subsystem}

User friendly interfaces were designed and implemented to manage the model runs. Some of those were developed to facilitate the process of data entry and the others to display the output of the model. Through the data entry screen, the user can select the crop for which it is required to develop its irrigation water economic value map. The crops through the previous screen were categorized into nine main categories that are cereal, fiber, vegetables, fruits, sugar crops, oil crops, legumes, forages, and herbalist. The results of DSS-EVIW could be demonstrated in reports and maps format.

\section{Application of DSS-EVIW}

Data and information for years 2008 and 2009 were collected, adjusted and uploaded to DSS-EVIW. These data were collected from Ministry of Agricultural and Land Reclamation, Ministry of Irrigation and Water Resources, and literature review. The collected data include: (1) the cultivated area in each governorate of Egypt for 45 crops, (2) the costs of cultivating the 45 crops which include preparation of the agricultural land, seeds, irrigation, fertilization, agricultural service, pests' resistance, harvest, transportation of the crop, public expenditures, and rent of the land, (3) the total revenue from the 45 crops which include the value of the main crop and the value of the secondary crop, and (4) water applied for cultivating the different crops.

\section{Analysis and results}

Economic values of irrigation water

The calculated economic values of irrigation water through DSS-EVIW for the 45 crop categorized on cereal, fiber, vegetables, fruits, sugar crops, oil crops, legumes, forages, and herbalist at different governorates of Egypt ranked from higher to lower economic value are shown in Appendix Tables 2, 3 and 4). These economic values for irrigation water are provided for the 45 crops in the form of maps. Figure 3 shows as example the developed water economic value map for wheat (average of years 2008-2009).

Crops of the highest and lowest economic value of irrigation water

The analysis of the results shows that the economic value of irrigation water applied for eggplant in Monofia reaches the highest value generated from irrigation water use in crops production (average of years 2008-2009), while the economic value of irrigation water applied for henna in Aswan governorate reaches the lowest value generated from water use in crops production (average of years 2008-2009) as shown in Fig. 4. Figure 4 presents the economic value of irrigation water for 45 crops at different governorates of Egypt ranked from the highest to the lowest one.

Economic values of irrigation water for the crop categories

The calculated economic values of irrigation water for the crop categories at different governorates of Egypt are ranked from higher to lower economic value, as shown in Table 1. Analysis of the results shows that wheat, flax, broad bean, sugar beet, peanut, roselle, tahrish and eggplant winter reached the highest values generated from water use in the crop production average of years 2008 and 2009 with values $2.49,2.28,2.08,2.05$, $1.62,1.13,2.85$, and $10.03 \mathrm{LE} / \mathrm{m}^{3}$ in cereal, fibber, legumes, sugar crops, oil crops, herbalsim, forages, and vegetables categories at Beheira, Kafr el-Sheikh, Gharbia, Al-Minya, Giza, Asyut, Giza, and Monufia governorates, respectively. While, 
Fig. 3 Developed water economic value map of wheat (average of years 2008-2009)

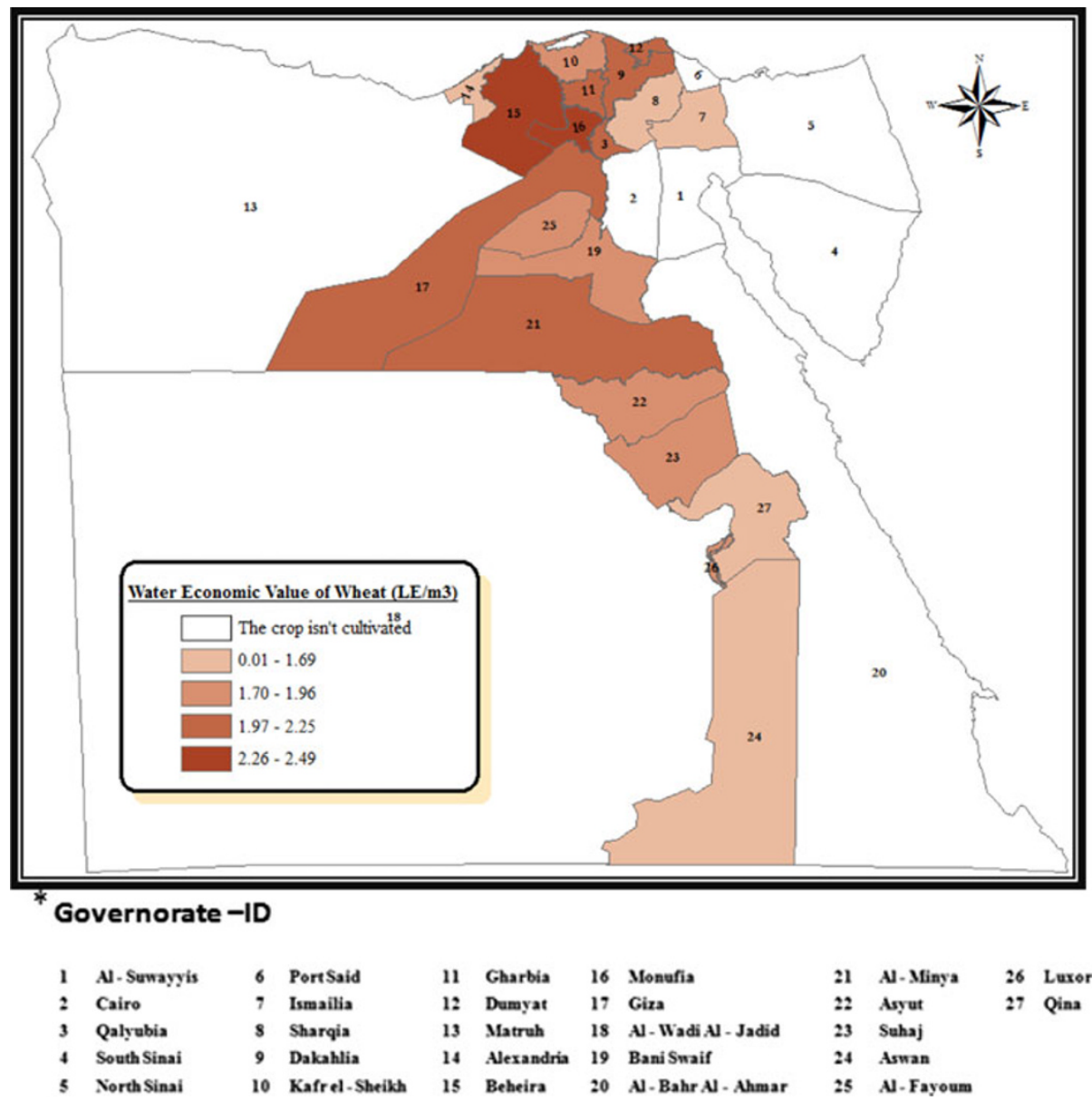

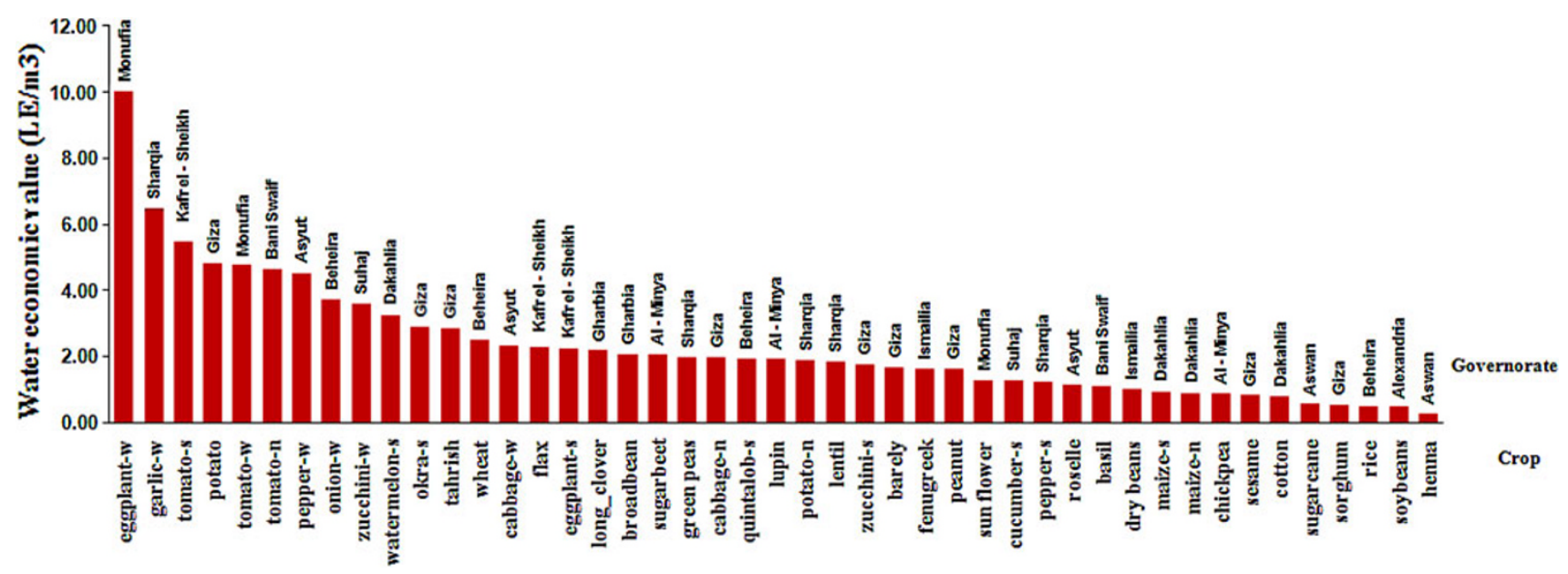

Fig. 4 Economic value of irrigation water for 45 crops at different governorates of Egypt ranked from the highest to the lowest one

rice, cotton, chickpea, sugarcane, soybeans, henna, long clover and pepper summer reached the lowest values generated from water use in crops' production in years 2008 and 2009 with values $0.49,0.79,0.86,0.86,0.57,0.47,0.29,2.19$, and $1.24 \mathrm{LE} / \mathrm{m}^{3}$ in cereal, fibber, legumes, sugar crops, oil crops, herbalsim, forages, and vegetables categories at el Behera, Dakahlia, Al-Minya, Aswan, Alexandria, Aswan, Gharbia, and Sharqia governorates, respectively.
Relation between cultivated areas and the economic value of irrigation water

As shown in Figs. 5 and 6 in spite of the economic value of irrigation water for wheat, as an example, in Sharqia is lower than its value at el Behera governorate, the cultivated area of wheat at Sharqia governorate is larger than its area at el Behera governorate. This concludes that the cultivated 
area of the crop at the different governorates is not related to its economic value. The previous analysis recommends the selection of the cropping pattern that increase the cultivated areas at the governorate based on the highest economic value for irrigation water.

Variation in the economic value of irrigation water

As shown in Fig. 7, although the applied water for cultivating wheat crop in Behera and Sharquia governorates (the two governorates are located in the same region that is lower Egypt) is equal, the economic values of wheat irrigation water in Behera governorate $(2.49 \mathrm{LE} / \mathrm{m})$ is higher than that in Sharqia governorate $\left(1.69 \mathrm{LE} / \mathrm{m}^{3}\right)$.

As shown in Fig. 8, the net return and the total cost and revenue per feddan for cultivating wheat crop in each governorate of Egypt in year 2009 are different from one governorate to the other even in the governorates that are located in the same region (lower, middle, and upper Egypt). The costs include the costs of preparing the land, irrigation, field rent, fertilizer, labors, seed, pesticides, harvesting, and transfer to market.

Therefore, it is concluded that the economic value of irrigation water of the same crop varies from one governorate to the other even in the same region. In the same region, the variation in the economic value of irrigating crop is due to the variations in the costs and revenue of the crop production and not to the variation in quantity of applied water. While, in different regions, the variation in economic value of irrigation water of a crop is due to the variations in the costs and revenue of the crop production and the quantity of irrigation water.

\section{Conclusions}

The current study succeeded to develop a Decision Support System to help in the integrated water resources management by computing and implementing economic value maps for irrigation water of Egypt. The DSS was applied to develop economic value maps of irrigation water for cultivating 45 crops under cereal, fiber, vegetables, fruits, sugar crops, oil crops, legumes, forages, and herbalist categories.

Crops of the highest and lowest economic value of irrigation water were determined. The economic value of irrigation water applied for eggplant in Monofia reaches the highest value generated from irrigation water use in crops production (average of years 2008-2009), while the economic value of irrigation water applied for henna in Aswan governorate reaches the lowest value generated from water use in crops production (average of years 2008-2009). Analysis of the developed maps shows that wheat, flax, broad bean, sugar beet, peanut, roselle, tahrish and
Table 1 Crops of the highest economic value of irrigation water

\begin{tabular}{|c|c|c|c|}
\hline Category & Crop & Governorate & $\begin{array}{l}\text { Highest economic } \\
\text { value of irrigation } \\
\text { water }\left(\mathrm{LE} / \mathrm{m}^{3}\right)\end{array}$ \\
\hline \multirow[t]{6}{*}{ Cereal } & Wheat & Beheira & 2.49 \\
\hline & Baraly & Giza & 1.96 \\
\hline & Summer maize & Dakahlia & 0.94 \\
\hline & Nili maize & Dakahlia & 0.90 \\
\hline & Sorghum & Giza & 0.55 \\
\hline & Rice & Beheira & 0.49 \\
\hline \multirow[t]{2}{*}{ Fibber } & Flax & Kafr el-Sheikh & 2.28 \\
\hline & Cotton & Dakahlia & 0.79 \\
\hline \multirow[t]{7}{*}{ Legumes } & Broad bean & Gharbia & 2.08 \\
\hline & Green peas & Sharqia & 2.00 \\
\hline & Lupin & Al-Minya & 1.93 \\
\hline & Lentil & Sharqia & 1.83 \\
\hline & Fenugreek & Ismailia & 1.64 \\
\hline & Dry beans & Ismailia & 1.00 \\
\hline & Chickpea & Al-Minya & 0.86 \\
\hline \multirow[t]{2}{*}{ Sugar } & Sugarbeet & Al-Minya & 2.05 \\
\hline & Sugarcane & Aswan & 0.57 \\
\hline \multirow[t]{4}{*}{ Oil } & Peanut & Giza & 1.62 \\
\hline & Sun flower & Monufia & 1.30 \\
\hline & Sesame & Giza & 0.83 \\
\hline & Soybeans & Alexandria & 0.47 \\
\hline \multirow[t]{3}{*}{ Herbalism } & Roselle & Asyut & 1.13 \\
\hline & Basil & Bani Swaif & 1.12 \\
\hline & Henna & Aswan & 0.29 \\
\hline \multirow[t]{2}{*}{ Forages } & Tahrish & Giza & 2.85 \\
\hline & Long_clover & Gharbia & 2.19 \\
\hline \multirow[t]{19}{*}{ Vegetables } & Eggplant-w & Monufia & 10.03 \\
\hline & Garlic-w & Sharqia & 6.48 \\
\hline & Tomato-s & Kafr el-Sheikh & 5.49 \\
\hline & Potato & Giza & 4.84 \\
\hline & Tomato-w & Monufia & 4.76 \\
\hline & Tomato-n & Bani Swaif & 4.63 \\
\hline & Pepper-w & Asyut & 4.53 \\
\hline & Onion-w & Beheira & 3.75 \\
\hline & Zucchini-w & Suhaj & 3.58 \\
\hline & Watermelon-s & Dakahlia & 3.26 \\
\hline & Okra-s & Giza & 2.90 \\
\hline & Cabbage-w & Asyut & 2.34 \\
\hline & Eggplant-s & Kafr el-Sheikh & 2.26 \\
\hline & Cabbage-n & Giza & 1.99 \\
\hline & Quintalob-s & Beheira & 1.96 \\
\hline & Potato-n & Sharqia & 1.91 \\
\hline & Zucchini-s & Giza & 1.77 \\
\hline & Cucumber-s & Suhaj & 1.28 \\
\hline & Pepper-s & Sharqia & 1.24 \\
\hline
\end{tabular}

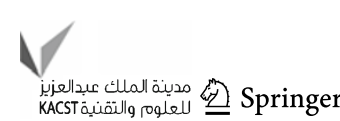




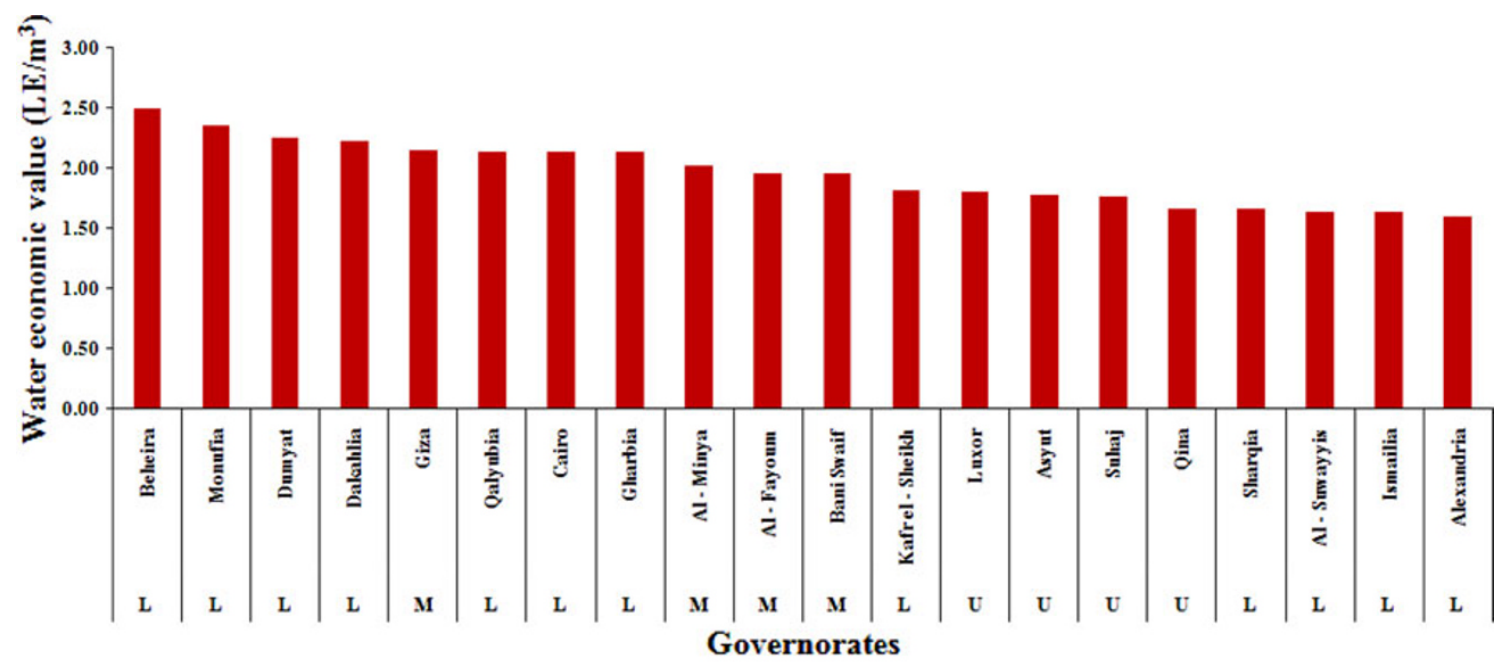

\section{Lower Egypt M Middle Egypt U upper Egypt}

Fig. 5 The calculated economic value of irrigation water for wheat at different governorates ranked from highest to lowest one (average of years 2008-2009)

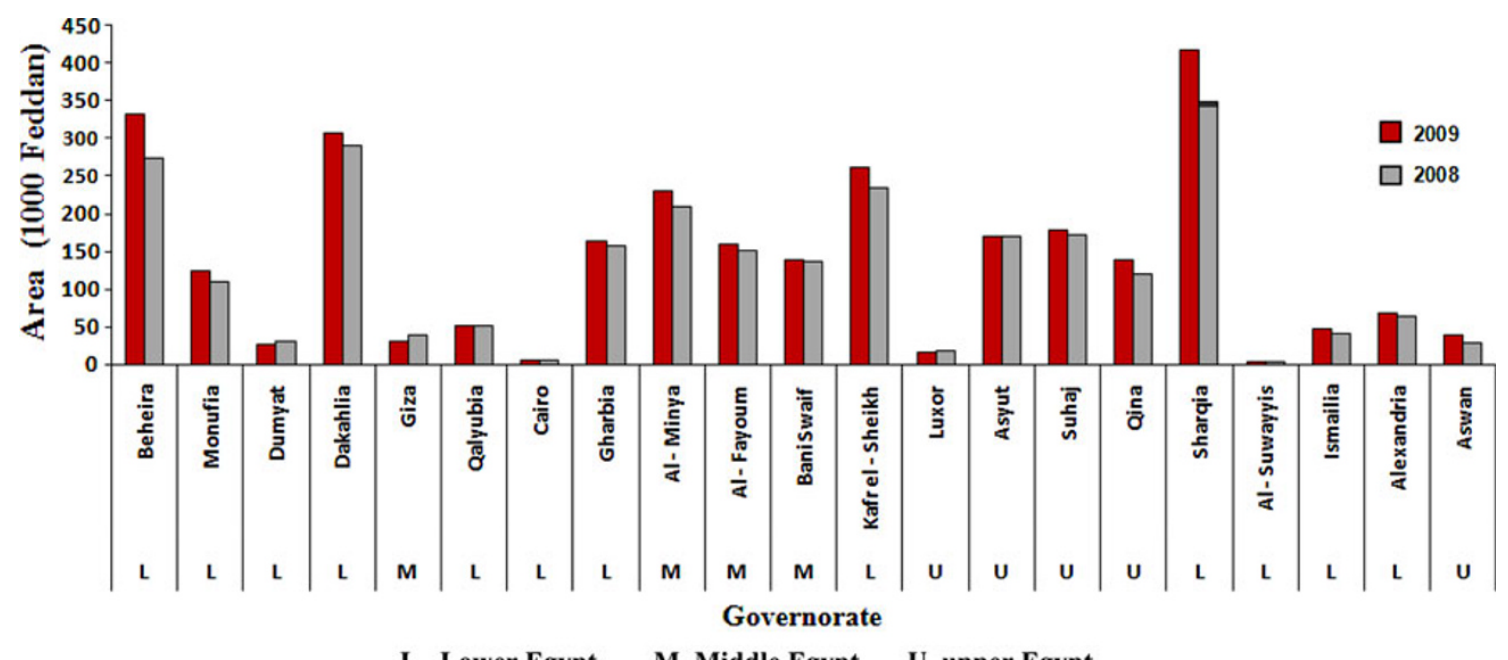

L Lower Egypt M Middle Egypt U upper Egypt

Fig. 6 The cultivated area of wheat at different governorates (2008-2009)

eggplant winter reached the highest values generated from water use in the crops production in years 2008 and 2009 with values $2.49,2.28,2.08,2.05,1.62,1.13,2.85$, and $10.03 \mathrm{LE} / \mathrm{m}^{3}$ in cereal, fibber, legumes, sugar crops, oil crops, herbalsim, forages, and vegetables categories at Beheira, Kafr el-Sheikh, Gharbia, Al-Minya, Giza, Asyut, Giza, and Monufia governorates, respectively. While, rice, cotton, chickpea, sugarcane, soybeans, henna, long clover and pepper summer reached the lowest values generated from water use in crops production in year 2008 and 2009 with a values $0.49,0.79,0.86,0.86,0.57,0.47,0.29,2.19$, and $1.24 \mathrm{LE} / \mathrm{m}^{3}$ in cereal, fibber, legumes, sugar crops, oil crops, herbalsim, forages, and vegetables categories at el
Behera, Dakahlia, Al- Minya, Aswan, Alexandria, Aswan, Gharbia, and Sharqia governorates, respectively.

The study showed that the cultivated area of the crop at the different governorates is not related to its economic value. Where, the cropping pattern is not selected in a way that increases the cultivated areas at the governorate based on the economic value of irrigation water. Moreover, the study shows that the economic value of the crop does not depend on the region. The economic values of irrigation water vary from one governorate to the other even in the same region (lower, middle, and upper Egypt). In the same region the variation in economic value of irrigation water is due to the variations in the costs and revenue of the crop 


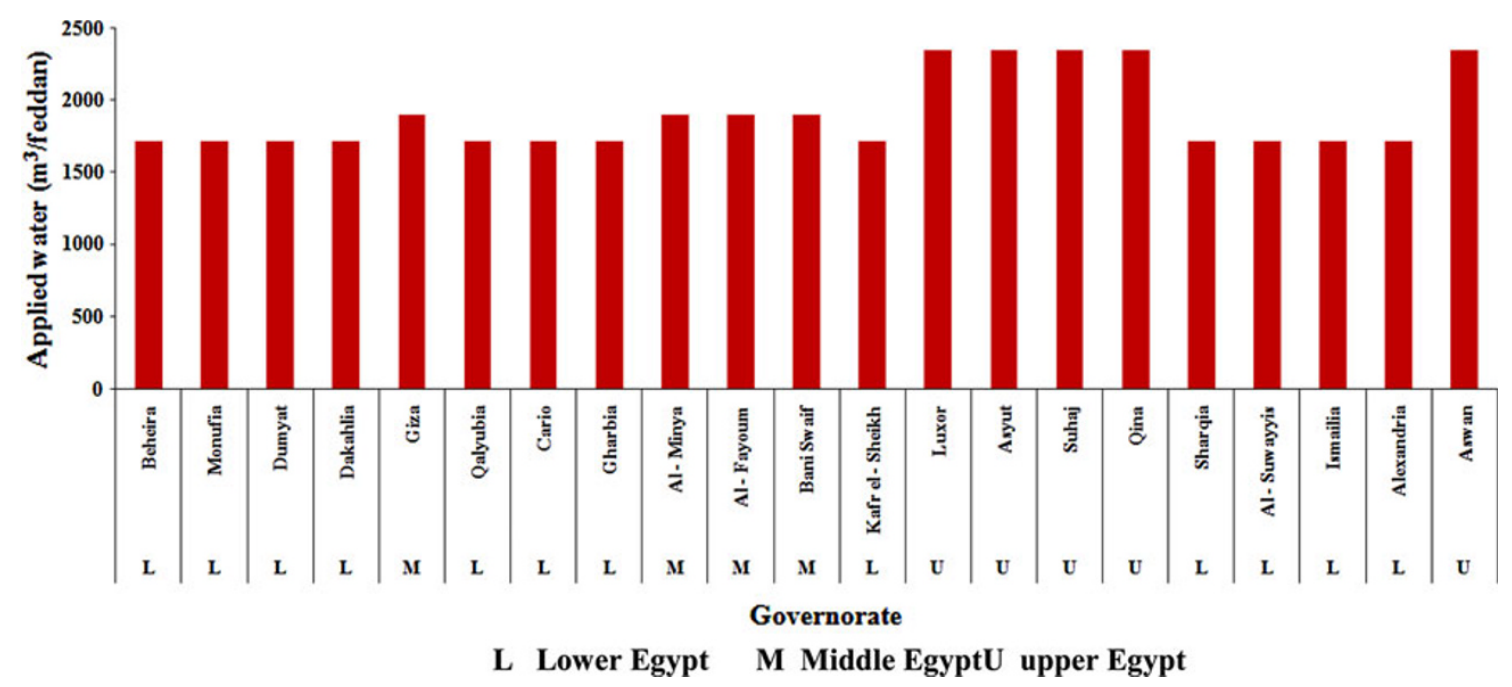

Fig. 7 Applied water per feddan used for cultivating wheat crop in year 2009

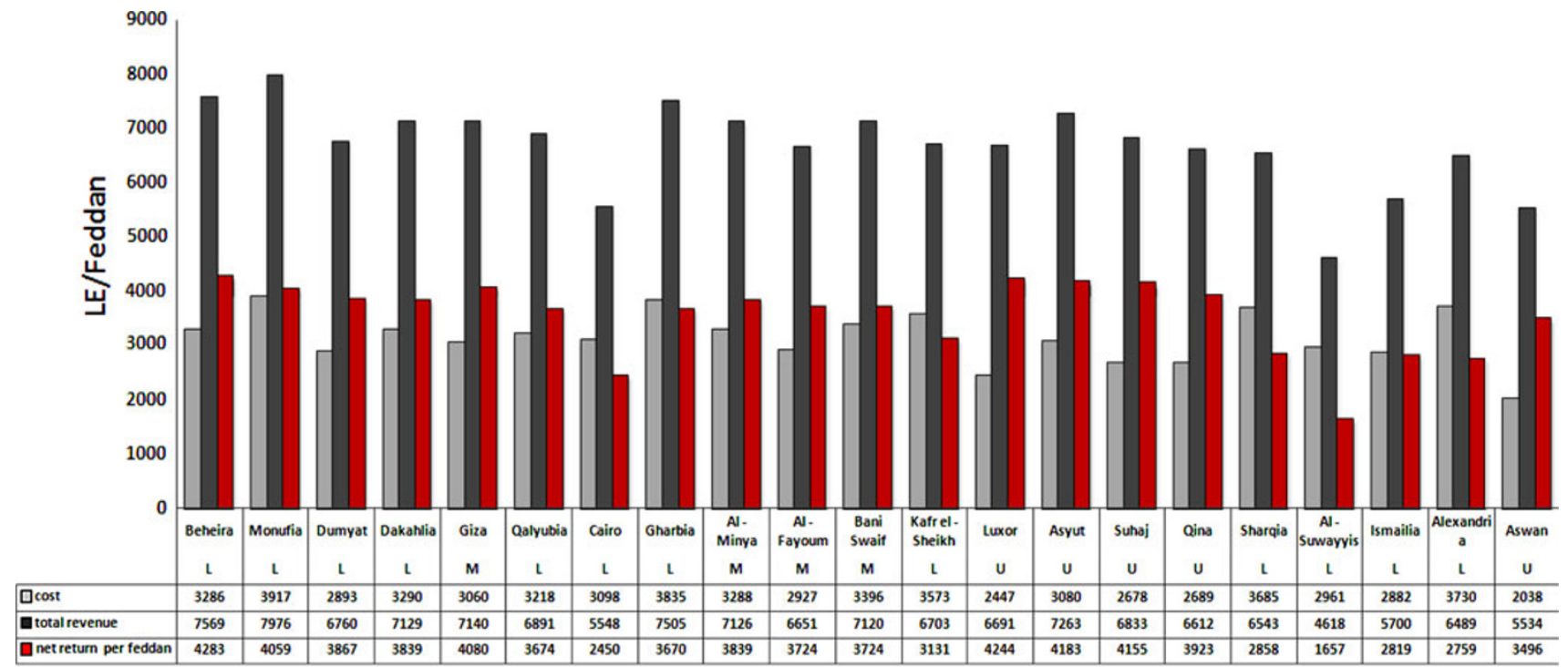

\section{Lower Egypt M Middle Egypt U upper Egypt}

Fig. 8 Net retune, total cost and revenue per feddan for wheat crop in year 2009

production and not to the variation in the quantity of irrigation water. While, in different regions the variation in economic value of irrigation water of the crop is due to the variations in the costs and revenue of the crop production and the quantity of irrigation water. The reasons of the cost changes at different governorates should be studied.

It is recommended to propose a cropping pattern that increases the cultivated areas for the crop at the governorate where the economic value of irrigation water for that crop achieve a high economic value. Based on the results, it is recommended to apply the developed DSS to evaluate the economic performance of water use in the crop production each year. The calculated and developed economic value of irrigation water maps can be used in proposing cropping pattern that maximizes the economic value of irrigation water in Egypt. Researchers and decision makers can then better target resource (re)allocation and measures to enhance water economic value in the agricultural sector.

Open Access This article is distributed under the terms of the Creative Commons Attribution License which permits any use, distribution and reproduction in any medium, provided the original author(s) and source are credited.

\section{Appendix}

See Tables 2, 3 and 4. 


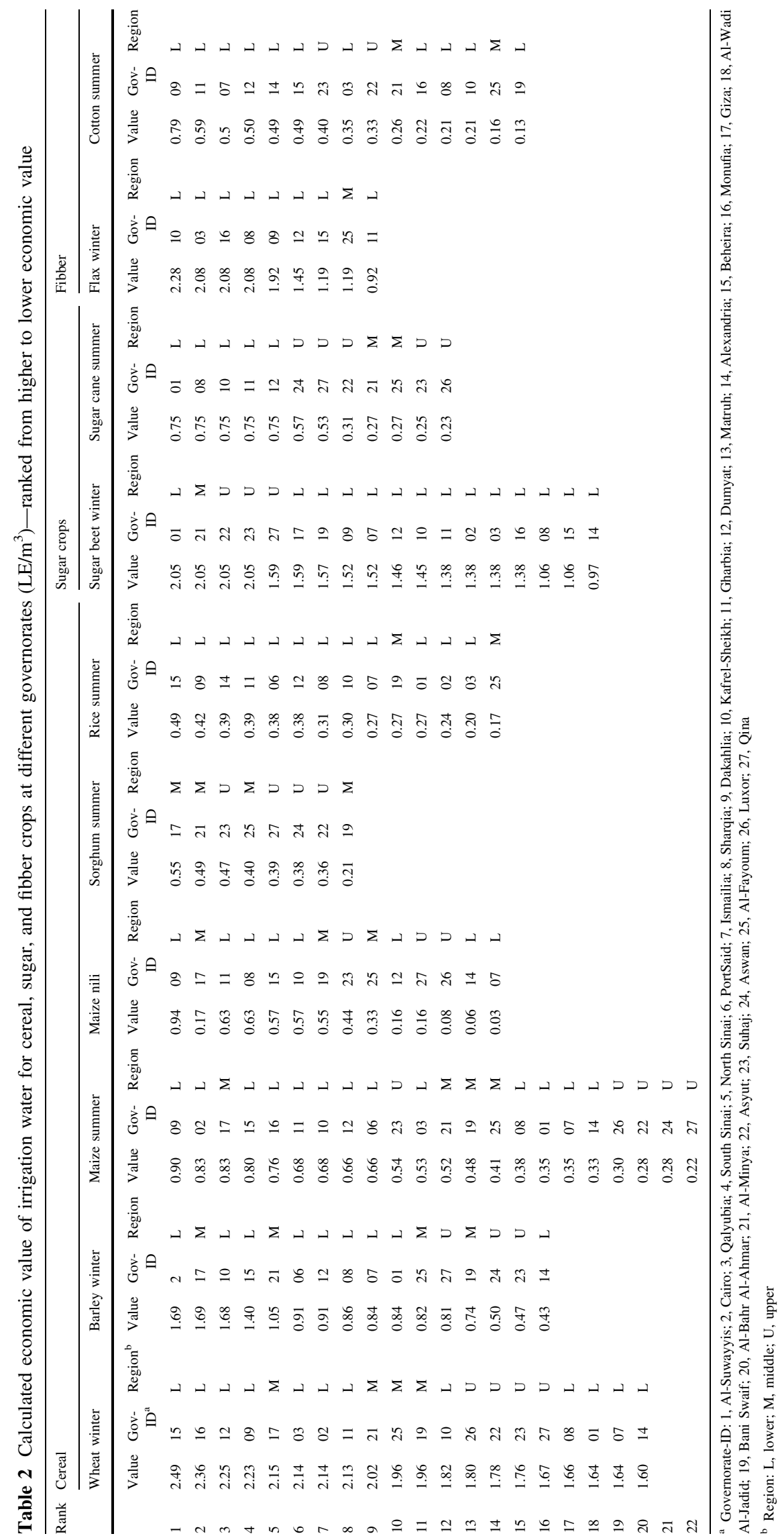


Table 3 Calculated economic value of irrigation water for legumes and herbalist crops at different governorates (LE/ $\left.\mathrm{m}^{3}\right)$-ranked from higher to lower one

\begin{tabular}{|c|c|c|c|c|c|c|c|c|c|c|c|c|c|c|c|}
\hline \multirow[t]{3}{*}{ Rank } & \multicolumn{15}{|c|}{ Legumes } \\
\hline & \multicolumn{3}{|c|}{ Broad bean winter } & \multicolumn{3}{|c|}{ Green bean winter } & \multicolumn{3}{|c|}{ Lupine winter } & \multicolumn{3}{|c|}{ Lentil winter } & \multicolumn{3}{|c|}{ Fenugreek winter } \\
\hline & Value & Gov-ID ${ }^{\mathrm{a}}$ & Region $^{\mathrm{b}}$ & Value & Gov-ID & Region & Value & Gov-ID & Region & Value & Gov-ID & Region & Value & Gov-ID & Region \\
\hline 1 & 2.08 & 09 & $\mathrm{~L}$ & 2.00 & 14 & $\mathrm{~L}$ & 1.93 & 21 & $\mathrm{M}$ & 1.83 & 08 & $\mathrm{~L}$ & 1.64 & 02 & $\mathrm{~L}$ \\
\hline 2 & 1.83 & 15 & $\mathrm{~L}$ & 1.27 & 03 & $\mathrm{~L}$ & 1.05 & 08 & $\mathrm{~L}$ & 1.10 & 27 & $\mathrm{U}$ & 1.64 & 07 & $\mathrm{~L}$ \\
\hline 3 & 1.74 & 23 & $\mathrm{~L}$ & 1.15 & 09 & $\mathrm{~L}$ & 0.65 & 23 & $\mathrm{U}$ & 1.10 & 21 & M & 1.46 & 25 & M \\
\hline 4 & 1.61 & 08 & $\mathrm{~L}$ & 1.15 & 10 & $\mathrm{~L}$ & 0.65 & 27 & $\mathrm{U}$ & 1.04 & 22 & $\mathrm{U}$ & 1.29 & 23 & $\mathrm{U}$ \\
\hline 5 & 1.54 & 21 & $\mathrm{U}$ & 1.06 & 02 & $\mathrm{~L}$ & 0.38 & 07 & $\mathrm{~L}$ & & & & 1.26 & 17 & M \\
\hline 6 & 1.41 & 24 & $\mathrm{~L}$ & 1.06 & 17 & M & 0.19 & 22 & $\mathrm{U}$ & & & & 1.19 & 27 & $\mathrm{U}$ \\
\hline 7 & 1.29 & 22 & M & 0.78 & 08 & $\mathrm{~L}$ & & & & & & & 1.14 & 21 & M \\
\hline 8 & 1.28 & 25 & M & 0.65 & 11 & $\mathrm{~L}$ & & & & & & & 1.07 & 19 & M \\
\hline 9 & 1.28 & 27 & $\mathrm{U}$ & 0.63 & 16 & $\mathrm{~L}$ & & & & & & & 0.59 & 22 & $\mathrm{U}$ \\
\hline 10 & 1.26 & 14 & $\mathrm{U}$ & 0.60 & 21 & M & & & & & & & 0.44 & 08 & $\mathrm{~L}$ \\
\hline 11 & 1.21 & 10 & $\mathrm{U}$ & 0.60 & 15 & $\mathrm{~L}$ & & & & & & & & & \\
\hline 12 & 1.07 & 06 & $\mathrm{~L}$ & 0.51 & 19 & M & & & & & & & & & \\
\hline 13 & 0.92 & 12 & $\mathrm{~L}$ & 0.48 & 01 & $\mathrm{~L}$ & & & & & & & & & \\
\hline 14 & 0.92 & 17 & $\mathrm{~L}$ & 0.48 & 07 & $\mathrm{~L}$ & & & & & & & & & \\
\hline 15 & 0.85 & 19 & $\mathrm{~L}$ & 0.33 & 25 & M & & & & & & & & & \\
\hline 16 & 0.78 & 03 & $\mathrm{M}$ & & & & & & & & & & & & \\
\hline 17 & 0.75 & 16 & M & & & & & & & & & & & & \\
\hline 18 & 0.73 & 26 & $\mathrm{~L}$ & & & & & & & & & & & & \\
\hline 19 & 0.72 & 07 & $\mathrm{~L}$ & & & & & & & & & & & & \\
\hline 20 & 0.62 & 09 & $\mathrm{U}$ & & & & & & & & & & & & \\
\hline \multirow[t]{3}{*}{ Rank } & \multicolumn{6}{|c|}{ Legumes } & \multicolumn{9}{|c|}{ Herbalist } \\
\hline & \multicolumn{3}{|c|}{ Dry been summer } & \multicolumn{3}{|c|}{ Chickpea winter } & \multicolumn{3}{|c|}{ Roselle summer } & \multicolumn{3}{|c|}{ Basil summer } & \multicolumn{3}{|c|}{ Henna summer } \\
\hline & Value & Gov-ID & Region & Value & Gov-ID & Region & Value & Gov-ID & Region & Value & Gov-ID & Region & Value & Gov-ID & Region \\
\hline 1 & 1.00 & 16 & $\mathrm{~L}$ & 0.86 & 21 & M & 1.13 & 22 & $\mathrm{U}$ & 1.12 & 19 & M & 0.29 & 24 & $\mathrm{U}$ \\
\hline 2 & 0.44 & 15 & $\mathrm{~L}$ & 0.51 & 22 & $\mathrm{U}$ & 0.64 & 24 & $\mathrm{U}$ & 1.03 & 25 & $\mathrm{U}$ & & & \\
\hline 3 & & & & 0.46 & 15 & $\mathrm{~L}$ & 0.63 & 27 & $\mathrm{U}$ & 0.76 & 22 & $\mathrm{U}$ & & & \\
\hline 4 & & & & 0.28 & 27 & $\mathrm{U}$ & & & & & & & & & \\
\hline 5 & & & & 0.28 & 26 & $\mathrm{U}$ & & & & & & & & & \\
\hline 6 & & & & 0.12 & 19 & M & & & & & & & & & \\
\hline 7 & & & & 0.86 & 21 & M & & & & & & & & & \\
\hline 8 & & & & 0.51 & 22 & $\mathrm{U}$ & & & & & & & & & \\
\hline 9 & & & & 0.46 & 15 & $\mathrm{~L}$ & & & & & & & & & \\
\hline 10 & & & & 0.28 & 27 & $\mathrm{U}$ & & & & & & & & & \\
\hline 11 & & & & 0.28 & 26 & $\mathrm{U}$ & & & & & & & & & \\
\hline 12 & & & & 0.12 & 19 & M & & & & & & & & & \\
\hline
\end{tabular}

${ }^{a}$ Governorate-ID: 1, Al-Suwayyis; 2, Cairo; 3, Qalyubia; 4, South Sinai; 5, North Sinai; 6, PortSaid; 7, Ismailia; 8, Sharqia; 9, Dakahlia; 10, Kafrel-Sheikh; 11, Gharbia; 12, Dumyat; 13, Matruh; 14, Alexandria; 15, Beheira; 16, Monufia; 17, Giza; 18, Al-Wadi Al-Jadid; 19, Bani Swaif; 20, Al-Bahr Al-Ahmar; 21, Al-Minya; 22, Asyut; 23, Suhaj; 24, Aswan; 25, Al-Fayoum; 26, Luxor; 27, Qina

${ }^{\mathrm{b}}$ Region: L, lower; M, middle; U, upper 
Table 4 Calculated economic value of irrigation water for oil, forages, and vegetables crops at different governorates (LE/ $\left.\mathrm{m}^{3}\right)$ ranked from higher to lower economic value

\begin{tabular}{|c|c|c|c|c|c|c|c|c|c|c|c|c|c|c|c|c|c|c|}
\hline \multirow[t]{3}{*}{ Rank } & \multicolumn{12}{|l|}{ Oil } & \multicolumn{6}{|c|}{ Forages } \\
\hline & \multicolumn{3}{|c|}{ Peanut summer } & \multicolumn{3}{|c|}{ Sun flower summer } & \multicolumn{3}{|c|}{ Sesame summer } & \multicolumn{3}{|c|}{ Soybeans summer } & \multicolumn{3}{|c|}{ Tahrish winter } & \multicolumn{3}{|c|}{ Long clover winter } \\
\hline & Value & $\begin{array}{l}\text { Gov- } \\
\text { ID }^{\mathrm{a}}\end{array}$ & Region $^{\mathrm{b}}$ & Value & $\begin{array}{l}\text { Gov- } \\
\text { ID }\end{array}$ & Region & Value & $\begin{array}{l}\text { Gov- } \\
\text { ID }\end{array}$ & Region & Value & $\begin{array}{l}\text { Gov- } \\
\text { ID }\end{array}$ & Region & Value & $\begin{array}{l}\text { Gov- } \\
\text { ID }\end{array}$ & Region & Value & $\begin{array}{l}\text { Gov- } \\
\text { ID }\end{array}$ & Region \\
\hline 1 & 1.62 & 17 & $\mathrm{M}$ & 1.30 & 14 & $\mathrm{~L}$ & 0.83 & 14 & M & 0.47 & 16 & $\mathrm{~L}$ & 2.85 & 17 & $\mathrm{M}$ & 2.19 & 11 & $\mathrm{~L}$ \\
\hline 2 & 1.32 & 02 & $\mathrm{~L}$ & 1.30 & 23 & $\mathrm{U}$ & 0.80 & 23 & $\mathrm{U}$ & 0.47 & 03 & $\mathrm{~L}$ & 2.44 & 21 & $\mathrm{M}$ & 2.15 & 03 & $\mathrm{~L}$ \\
\hline 3 & 1.32 & 3 & $\mathrm{~L}$ & 0.78 & 19 & $\mathrm{M}$ & 0.79 & 19 & $\mathrm{~L}$ & 0.43 & 21 & M & 2.42 & 25 & M & 2.09 & 10 & $\mathrm{~L}$ \\
\hline 4 & 1.19 & 23 & $\mathrm{U}$ & 0.52 & 21 & $\mathrm{M}$ & 0.70 & 21 & M & 0.16 & 19 & M & 2.34 & 19 & $\mathrm{M}$ & 2.08 & 17 & M \\
\hline 5 & 1.06 & 07 & $\mathrm{~L}$ & 0.32 & 22 & $\mathrm{U}$ & 0.64 & 22 & M & 0.16 & 23 & $\mathrm{U}$ & 2.30 & 16 & $\mathrm{~L}$ & 2.08 & 16 & $\mathrm{~L}$ \\
\hline 6 & 1.05 & 22 & $\mathrm{U}$ & 0.18 & 15 & $\mathrm{~L}$ & 0.63 & 15 & $\mathrm{U}$ & 0.16 & 25 & M & 2.15 & 02 & $\mathrm{~L}$ & 2.06 & 12 & $\mathrm{~L}$ \\
\hline 7 & 1.04 & 15 & $\mathrm{~L}$ & 0.16 & 03 & $\mathrm{~L}$ & 0.59 & 03 & $\mathrm{U}$ & 0.16 & 24 & $\mathrm{U}$ & 2.15 & 03 & $\mathrm{~L}$ & 2.06 & 9 & $\mathrm{~L}$ \\
\hline 8 & 0.96 & 16 & $\mathrm{~L}$ & 0.16 & 25 & $\mathrm{M}$ & 0.58 & 25 & M & 0.16 & 22 & $\mathrm{U}$ & 2.12 & 11 & $\mathrm{~L}$ & 2.05 & 15 & $\mathrm{~L}$ \\
\hline 9 & 0.96 & 8 & $\mathrm{~L}$ & 0.15 & 14 & $\mathrm{~L}$ & 0.51 & 14 & $\mathrm{U}$ & & & & 2.07 & 10 & $\mathrm{~L}$ & 2.05 & 14 & $\mathrm{~L}$ \\
\hline 10 & 0.86 & 24 & $\mathrm{U}$ & 1.30 & 23 & $\mathrm{U}$ & 0.47 & 23 & $\mathrm{~L}$ & & & & 2.05 & 15 & $\mathrm{~L}$ & 1.98 & 08 & $\mathrm{~L}$ \\
\hline 11 & 0.86 & 26 & $\mathrm{U}$ & 1.30 & 19 & $\mathrm{M}$ & 0.47 & 19 & $\mathrm{~L}$ & & & & 2.01 & 09 & $\mathrm{~L}$ & 1.98 & 01 & $\mathrm{~L}$ \\
\hline 12 & 0.86 & 27 & $\mathrm{U}$ & 0.78 & 21 & M & 0.45 & 21 & $\mathrm{~L}$ & & & & 2.01 & 07 & $\mathrm{~L}$ & 1.98 & 07 & $\mathrm{~L}$ \\
\hline 13 & 0.79 & 21 & $\mathrm{M}$ & 0.52 & 22 & $\mathrm{U}$ & 0.45 & 22 & $\mathrm{~L}$ & & & & 1.99 & 08 & $\mathrm{~L}$ & 1.86 & 25 & $\mathrm{M}$ \\
\hline 14 & 0.5 & 25 & $\mathrm{M}$ & 0.32 & 15 & $\mathrm{~L}$ & 0.45 & 15 & $\mathrm{~L}$ & & & & 1.83 & 22 & $\mathrm{U}$ & 1.85 & 21 & M \\
\hline 15 & 0.50 & 19 & M & 0.18 & 03 & $\mathrm{~L}$ & 0.45 & 03 & $\mathrm{~L}$ & & & & 1.68 & 23 & $\mathrm{U}$ & 1.80 & 19 & M \\
\hline 16 & & & & & & & & & & & & & 0.98 & 12 & $\mathrm{~L}$ & 1.53 & 24 & $\mathrm{U}$ \\
\hline 17 & & & & & & & & & & & & & & & & 1.53 & 26 & $\mathrm{U}$ \\
\hline 18 & & & & & & & & & & & & & & & & 1.45 & 23 & $\mathrm{U}$ \\
\hline 19 & & & & & & & & & & & & & & & & 1.42 & 22 & $\mathrm{U}$ \\
\hline \multicolumn{19}{|l|}{20} \\
\hline \multirow[t]{3}{*}{ Rank } & \multicolumn{18}{|c|}{ Vegetables } \\
\hline & \multicolumn{5}{|c|}{ Eggplant winter } & \multicolumn{4}{|c|}{ Garlic winter } & \multicolumn{5}{|c|}{ Tomato summer } & \multicolumn{4}{|c|}{ Potato summer } \\
\hline & Val & & Gov-ID & Regi & & Value & Gov-I & & Region & Valu & & Gov-ID & Regic & & Value & Gov-II & & Region \\
\hline 1 & 10.0 & & 16 & $\mathrm{~L}$ & & 6.48 & 16 & & $\mathrm{~L}$ & 5.49 & & 10 & $\mathrm{~L}$ & & 4.84 & 17 & & M \\
\hline 2 & 9.33 & & 8 & $\mathrm{~L}$ & & 6.48 & 08 & & $\mathrm{~L}$ & 5.29 & & 17 & M & & 3.18 & 07 & & $\mathrm{~L}$ \\
\hline 3 & 7.98 & & 9 & $\mathrm{~L}$ & & 6.35 & 02 & & $\mathrm{~L}$ & 4.11 & & 7 & $\mathrm{~L}$ & & 2.94 & 08 & & $\mathrm{~L}$ \\
\hline 4 & 6.58 & & 3 & $\mathrm{~L}$ & & 6.35 & 03 & & $\mathrm{~L}$ & 3.40 & & 19 & M & & 2.52 & 22 & & $\mathrm{U}$ \\
\hline 5 & 6.36 & & 7 & $\mathrm{~L}$ & & 6.22 & 15 & & $\mathrm{~L}$ & 3.4 & & 25 & $\mathrm{U}$ & & 2.49 & 03 & & $\mathrm{~L}$ \\
\hline 6 & 6.34 & & 22 & $\mathrm{U}$ & & 5.54 & 22 & & $\mathrm{U}$ & 3.01 & & 23 & $\mathrm{U}$ & & 2.49 & 12 & & $\mathrm{~L}$ \\
\hline 7 & 4.91 & & 15 & $\mathrm{~L}$ & & 5.40 & 23 & & $\mathrm{U}$ & 2.92 & & 3 & $\mathrm{~L}$ & & 2.49 & 02 & & $\mathrm{~L}$ \\
\hline 8 & 4.81 & & 21 & $\mathrm{M}$ & & 5.14 & 19 & & M & 2.67 & & 26 & $\mathrm{U}$ & & 2.32 & 14 & & $\mathrm{~L}$ \\
\hline 9 & 4.11 & & 24 & $\mathrm{U}$ & & 4.54 & 17 & & $\mathrm{M}$ & 2.67 & & 27 & $\mathrm{U}$ & & 2.18 & 11 & & $\mathrm{~L}$ \\
\hline 10 & $3.7 \mathrm{C}$ & & 25 & $\mathrm{U}$ & & 4.54 & 26 & & $\mathrm{U}$ & 2.62 & & 14 & $\mathrm{~L}$ & & 2.02 & 15 & & $\mathrm{~L}$ \\
\hline 11 & & & & & & 4.54 & 24 & & $\mathrm{U}$ & 2.50 & & 11 & $\mathrm{~L}$ & & 1.77 & 25 & & $\mathrm{U}$ \\
\hline 12 & & & & & & 4.48 & 11 & & $\mathrm{~L}$ & 2.39 & & 21 & M & & 1.77 & 19 & & M \\
\hline 13 & & & & & & 3.62 & 27 & & $\mathrm{U}$ & 1.92 & & 22 & $\mathrm{U}$ & & 1.65 & 23 & & $\mathrm{U}$ \\
\hline 14 & & & & & & 3.49 & 21 & & $\mathrm{M}$ & 1.86 & & 8 & $\mathrm{~L}$ & & 1.64 & 09 & & $\mathrm{~L}$ \\
\hline 15 & & & & & & 2.66 & 14 & & $\mathrm{~L}$ & 1.86 & & 16 & $\mathrm{~L}$ & & 1.49 & 16 & & $\mathrm{~L}$ \\
\hline 16 & & & & & & 2.33 & 25 & & $\mathrm{U}$ & 1.70 & & 9 & $\mathrm{~L}$ & & 0.69 & 21 & & M \\
\hline 17 & & & & & & 2.03 & 07 & & $\mathrm{~L}$ & & & & & & & & & \\
\hline 18 & & & & & & 2.03 & 1 & & $\mathrm{~L}$ & & & & & & & & & \\
\hline 19 & & & & & & 2.03 & 12 & & $\mathrm{~L}$ & & & & & & & & & \\
\hline 20 & & & & & & 2.03 & 09 & & $\mathrm{~L}$ & & & & & & & & & \\
\hline
\end{tabular}


Table 4 continued

\begin{tabular}{|c|c|c|c|c|c|c|c|c|c|c|c|c|c|c|c|c|c|c|}
\hline \multirow[t]{3}{*}{ Rank } & \multicolumn{18}{|c|}{ Vegetables } \\
\hline & \multicolumn{3}{|c|}{ Tomato winter } & \multicolumn{3}{|c|}{ Tomato nili } & \multicolumn{3}{|c|}{ Pepper winter } & \multicolumn{3}{|c|}{ Onion winter } & \multicolumn{3}{|c|}{ Zucchini winter } & \multicolumn{3}{|c|}{ Watermelon summer } \\
\hline & Value & $\begin{array}{l}\text { Gov- } \\
\text { ID }^{\mathrm{a}}\end{array}$ & Region $^{\mathrm{b}}$ & Value & $\begin{array}{l}\text { Gov- } \\
\text { ID }\end{array}$ & Region & Value & $\begin{array}{l}\text { Gov- } \\
\text { ID }\end{array}$ & Region & Value & $\begin{array}{l}\text { Gov- } \\
\text { ID }\end{array}$ & Region & Value & $\begin{array}{l}\text { Gov- } \\
\text { ID }\end{array}$ & Region & Value & $\begin{array}{l}\text { Gov- } \\
\text { ID }\end{array}$ & Region \\
\hline 1 & 4.76 & 16 & $\mathrm{~L}$ & 4.63 & 21 & M & 4.53 & 22 & $\mathrm{U}$ & 3.75 & 14 & $\mathrm{~L}$ & 3.58 & 23 & $\mathrm{U}$ & 3.26 & 09 & $\mathrm{~L}$ \\
\hline 2 & 4.45 & 23 & $\mathrm{U}$ & 4.63 & 19 & M & 4.08 & 08 & $\mathrm{~L}$ & 3.75 & 15 & $\mathrm{~L}$ & 2.36 & 17 & $\mathrm{M}$ & 1.81 & 14 & $\mathrm{~L}$ \\
\hline 3 & 4.43 & 26 & $\mathrm{U}$ & 4.33 & 1 & $\mathrm{~L}$ & 3.74 & 17 & $\mathrm{M}$ & 3.66 & 11 & $\mathrm{~L}$ & 2.34 & 14 & $\mathrm{~L}$ & 1.70 & 08 & $\mathrm{~L}$ \\
\hline 4 & 4.43 & 27 & $\mathrm{U}$ & 4.33 & 7 & $\mathrm{~L}$ & 2.87 & 25 & $\mathrm{U}$ & 3.25 & 07 & $\mathrm{~L}$ & 2.32 & 08 & $\mathrm{~L}$ & 1.63 & 10 & $\mathrm{~L}$ \\
\hline 5 & 4.29 & 01 & $\mathrm{~L}$ & 4.07 & 27 & $\mathrm{U}$ & 2.71 & 15 & $\mathrm{~L}$ & 3.25 & 01 & $\mathrm{~L}$ & 2.09 & 25 & $\mathrm{U}$ & 1.36 & 25 & $\mathrm{U}$ \\
\hline 6 & 4.29 & 07 & $\mathrm{~L}$ & 4.07 & 23 & $\mathrm{U}$ & 2.63 & 07 & $\mathrm{~L}$ & 3.25 & 13 & $\mathrm{~L}$ & 2.08 & 16 & $\mathrm{~L}$ & 1.32 & 15 & $\mathrm{~L}$ \\
\hline 7 & 3.92 & 10 & $\mathrm{~L}$ & 4.07 & 26 & $\mathrm{U}$ & 2.20 & 24 & $\mathrm{U}$ & 3.25 & 09 & $\mathrm{~L}$ & 1.74 & 22 & $\mathrm{U}$ & 1.25 & 19 & M \\
\hline 8 & 3.22 & 17 & M & 4.07 & 24 & $\mathrm{U}$ & 2.02 & 21 & $\mathrm{M}$ & 3.15 & 26 & $\mathrm{U}$ & 1.49 & 03 & $\mathrm{~L}$ & 1.10 & 07 & $\mathrm{~L}$ \\
\hline 9 & 2.97 & 19 & M & 3.70 & 25 & $\mathrm{U}$ & & & & 3.15 & 27 & $\mathrm{U}$ & 0.77 & 24 & $\mathrm{U}$ & 0.77 & 21 & M \\
\hline 10 & 2.63 & 22 & $\mathrm{U}$ & 3.39 & 17 & M & & & & 3.15 & 24 & $\mathrm{U}$ & 0.76 & 07 & $\mathrm{~L}$ & 0.41 & 24 & $\mathrm{U}$ \\
\hline 11 & 2.52 & 03 & $\mathrm{~L}$ & 1.78 & 09 & $\mathrm{~L}$ & & & & 3.03 & 03 & $\mathrm{~L}$ & 0.52 & 15 & $\mathrm{~L}$ & & & \\
\hline 12 & 2.52 & 08 & $\mathrm{~L}$ & 1.78 & 13 & $\mathrm{~L}$ & & & & 3.03 & 02 & $\mathrm{~L}$ & & & & & & \\
\hline 13 & 2.05 & 25 & $\mathrm{U}$ & 1.54 & 08 & $\mathrm{~L}$ & & & & 2.93 & 23 & $\mathrm{U}$ & & & & & & \\
\hline 14 & 2.01 & 21 & M & 1.54 & 16 & $\mathrm{~L}$ & & & & 2.85 & 08 & $\mathrm{~L}$ & & & & & & \\
\hline 15 & 1.44 & 14 & $\mathrm{~L}$ & 1.54 & 03 & $\mathrm{~L}$ & & & & 2.85 & 16 & $\mathrm{~L}$ & & & & & & \\
\hline 16 & 1.35 & 15 & $\mathrm{~L}$ & 1.54 & 11 & $\mathrm{~L}$ & & & & 2.81 & 25 & $\mathrm{U}$ & & & & & & \\
\hline 17 & 1.10 & 9 & $\mathrm{~L}$ & 1.54 & 02 & $\mathrm{~L}$ & & & & 2.70 & 22 & $\mathrm{U}$ & & & & & & \\
\hline 18 & 1.10 & 12 & $\mathrm{~L}$ & 1.52 & 14 & $\mathrm{~L}$ & & & & 2.67 & 17 & M & & & & & & \\
\hline 19 & & & & 1.42 & 15 & $\mathrm{~L}$ & & & & 2.67 & 19 & M & & & & & & \\
\hline 20 & & & & & & & & & & 2.38 & 21 & M & & & & & & \\
\hline \multicolumn{19}{|l|}{21} \\
\hline \multirow[t]{3}{*}{ Rank } & \multicolumn{18}{|c|}{ Vegetables } \\
\hline & \multicolumn{5}{|c|}{ Okra summer } & \multicolumn{4}{|c|}{ Cabbage winter } & \multicolumn{5}{|c|}{ Eggplant summer } & \multicolumn{4}{|c|}{ Cabbage nili } \\
\hline & Valu & & Gov-ID & Regio & & Value & Gov-II & & Region & Value & & Gov-ID & Regio & & Value & Gov-II & & Region \\
\hline 1 & 2.90 & & 17 & M & & 2.34 & 22 & & U & 2.26 & & 10 & $\mathrm{~L}$ & & 1.99 & 17 & & M \\
\hline 2 & 1.57 & & 15 & $\mathrm{~L}$ & & 2.25 & 17 & & M & 1.16 & & 15 & $\mathrm{~L}$ & & 1.78 & 03 & & $\mathrm{~L}$ \\
\hline 3 & 1.27 & & 24 & $\mathrm{U}$ & & 2.03 & 14 & & $\mathrm{~L}$ & 1.07 & & 09 & $\mathrm{~L}$ & & 1.43 & 16 & & $\mathrm{~L}$ \\
\hline 4 & 0.71 & & 14 & $\mathrm{~L}$ & & 2.00 & 08 & & $\mathrm{~L}$ & 1.05 & & 21 & M & & 1.14 & 09 & & $\mathrm{~L}$ \\
\hline 5 & 0.60 & & 25 & $\mathrm{U}$ & & 1.95 & 25 & & $\mathrm{U}$ & 1.01 & & 03 & $\mathrm{~L}$ & & 0.63 & 08 & & $\mathrm{~L}$ \\
\hline 6 & & & & & & 1.87 & 23 & & U & 0.89 & & 07 & $\mathrm{~L}$ & & & & & \\
\hline 7 & & & & & & 1.82 & 11 & & $\mathrm{~L}$ & 0.79 & & 08 & $\mathrm{~L}$ & & & & & \\
\hline 8 & & & & & & 1.76 & 03 & & $\mathrm{~L}$ & 0.64 & & 17 & M & & & & & \\
\hline 9 & & & & & & 1.50 & 15 & & $\mathrm{~L}$ & 0.45 & & 14 & $\mathrm{~L}$ & & & & & \\
\hline 10 & & & & & & 1.05 & 21 & & M & 0.38 & & 25 & $\mathrm{U}$ & & & & & \\
\hline 11 & & & & & & & & & & 0.18 & & 24 & $\mathrm{U}$ & & & & & \\
\hline
\end{tabular}


Table 4 continued

\begin{tabular}{|c|c|c|c|c|c|c|c|c|c|c|c|c|c|c|c|}
\hline \multirow[t]{3}{*}{ Rank } & \multicolumn{15}{|c|}{ Vegetables } \\
\hline & \multicolumn{3}{|c|}{ Qantalob nili } & \multicolumn{3}{|c|}{ Potato nili } & \multicolumn{3}{|c|}{ Zucchini summer } & \multicolumn{3}{|c|}{ Cucumber summer } & \multicolumn{3}{|c|}{ Pepper summer } \\
\hline & Value & Gov-ID ${ }^{\mathrm{a}}$ & Region $^{\mathrm{b}}$ & Value & Gov-ID & Region & Value & Gov-ID & Region & Value & Gov-ID & Region & Value & Gov-ID & Region \\
\hline 1 & 1.96 & 15 & $\mathrm{~L}$ & 1.91 & 07 & $\mathrm{~L}$ & 1.77 & 17 & M & 1.28 & 23 & $\mathrm{U}$ & 1.24 & 08 & $\mathrm{~L}$ \\
\hline 2 & 1.03 & 07 & $\mathrm{~L}$ & 1.91 & 09 & $\mathrm{~L}$ & 1.05 & 03 & $\mathrm{~L}$ & 0.86 & 19 & M & 1.22 & 17 & M \\
\hline 3 & 0.57 & 14 & $\mathrm{~L}$ & 1.91 & 08 & $\mathrm{~L}$ & 0.95 & 11 & $\mathrm{~L}$ & 0.75 & 15 & $\mathrm{~L}$ & 0.64 & 07 & $\mathrm{~L}$ \\
\hline 4 & & & & 1.91 & 06 & $\mathrm{~L}$ & 0.92 & 08 & $\mathrm{~L}$ & 0.73 & 21 & M & 0.47 & 27 & $\mathrm{U}$ \\
\hline 5 & & & & 1.74 & 17 & M & 0.78 & 15 & $\mathrm{~L}$ & 0.49 & 07 & $\mathrm{~L}$ & 0.43 & 15 & $\mathrm{~L}$ \\
\hline 6 & & & & 1.74 & 02 & $\mathrm{~L}$ & 0.68 & 07 & $\mathrm{~L}$ & 0.47 & 14 & $\mathrm{~L}$ & 0.25 & 14 & $\mathrm{~L}$ \\
\hline 7 & & & & 1.65 & 24 & $\mathrm{U}$ & 0.68 & 21 & M & 0.39 & 08 & $\mathrm{~L}$ & & & \\
\hline 8 & & & & 1.65 & 26 & $\mathrm{U}$ & 0.53 & 10 & $\mathrm{~L}$ & 0.39 & 10 & $\mathrm{~L}$ & & & \\
\hline 9 & & & & 1.65 & 27 & $\mathrm{U}$ & 0.47 & 25 & $\mathrm{U}$ & 0.21 & 17 & M & & & \\
\hline 10 & & & & 0.10 & 10 & $\mathrm{~L}$ & 0.43 & 14 & $\mathrm{~L}$ & 0.17 & 24 & $\mathrm{U}$ & & & \\
\hline 11 & & & & 0.98 & 25 & $\mathrm{U}$ & 0.27 & 24 & $\mathrm{U}$ & 1.28 & 23 & $\mathrm{U}$ & & & \\
\hline 12 & & & & 0.98 & 19 & M & & & & 0.86 & 19 & $\mathrm{M}$ & & & \\
\hline 13 & & & & 0.86 & 14 & $\mathrm{~L}$ & & & & 0.75 & 15 & $\mathrm{~L}$ & & & \\
\hline 14 & & & & & & & & & & 0.73 & 21 & M & & & \\
\hline
\end{tabular}

${ }^{a}$ Governorate-ID: 1, Al-Suwayyis; 2, Cairo; 3, Qalyubia; 4, South Sinai; 5, North Sinai; 6, PortSaid; 7, Ismailia; 8, Sharqia; 9 , Dakahlia; 10, Kafrel-Sheikh; 11, Gharbia; 12, Dumyat; 13, Matruh; 14, Alexandria; 15, Beheira; 16, Monufia; 17, Giza; 18, Al-Wadi Al-Jadid; 19, Bani Swaif; 20, Al-Bahr Al-Ahmar; 21, Al-Minya; 22, Asyut; 23, Suhaj; 24, Aswan; 25, Al-Fayoum; 26, Luxor; 27, Qina

${ }^{\mathrm{b}}$ Region: L, lower; M, middle; U, upper

\section{References}

Abu-Zeid M (2001) Water pricing in irrigated agriculture. Water Resour Dev 17(4):527-538

Agudelo JI (2001) The economic valuation of water: principles and methods, value of water research report series, report no 5, IHE, Delft, The Netherlands

Ashfaq M, Jabeen S, Baig A (2005) Estimation of the economic value of irrigation water. J Agric Soc Sci, 1813-2235/2005/01-3270-272, http://www.fspublishers.org/jass/past-issues/JASSVOL_ 1_NO_3/16.pdf, seen on December 2011

Attia B (2009) Assessment of vulnerability and adaptation of water resources to climate change in Egypt. http://www.arabwater council.org/administrator/Modules/Events/IWRA\%20Egypt\%20 Paper.pdf. Accessed 30 May 2009

CAPMAS (2010) Central Agency for Public Mobilization and Statistics. Egypt in Numbers, the Statistical Year Book, Cairo, Egypt

El-Atfy H, Kotb T (2004) Water valuing: a tool for demand management in Egypt, Workshop on Water Demand Management in Egypt, Framework of the 38th Meeting of the Advisory Panel Project on Water Management, Nigmegen, The Netherlands, http://www.app-wm.org/liberary/DownloadFiles.aspx? $\operatorname{did}=625973 \& d t=1$. Accessed Dec 2011

Hatfield L (2011) The future demands efficiency. http://e-ditions byfry.com/Olive/ODE/RES/default.aspx?href=RES\%2F $2011 \%$ $2 \mathrm{~F} 01 \% 2 \mathrm{~F} 01 \&$ pageno=3\&entity $=$ Ar00300\&view $=$ entity. Accessed Dec 2011

Kuo S, Liu C, Merkley G (2001) Application of the simulated annealing method to agricultural water resource management. J Agric Eng Res 80(1): 109-124. http://ntur.lib.ntu.edu.tw/bitstr eam/246246/175868/1/09.pdf. Accessed Dec 2011

MALR (2005) Ministry of Agricultural and Land Reclamation. Strategy of agricultural development in Egypt until 2017, Cairo, Egypt
MALR (2009) Ministry of Agricultural and Land Reclamation. Strategy of agricultural development in Egypt until 2030, Cairo, Egypt

MWRI (2005), Ministry of Water Resources and Irrigation. Integrated Water Resources Management Plane, Cairo, Egypt

MWRI (2010) Ministry of Water Resources and Irrigation. Integrated Water Resources Management Plane. Cairo, Egypt

Negm A, El-eshmawiy K, Abd Elfatah H, El-shiraif L (2006) The optimal Egyptian indicative cropping pattern using nonlinearfractional programming. J Appl Sci Res 2(2): 91-99 (INSInet Publication)

Salah I (2002) The economic efficiency of the water resources use in the agricultural sector, M. Sc. thesis, the Agricultural Economics department, Faculty of Agricultural, Monofia University, Egypt, March

Shahata A, Raghab H (2008) The optimal economic use of water resources in the Egyptian cropping pattern conference, the sixth conference of the Egyptian agriculture, Agricultural Economic Research Institute, Egypt, March

Shahata M (1993) An economic study of water use in agricultural in Egypt, Ph. D. Thesis, the agricultural economics department, Faculty of agricultural, Ain Shams University, Egypt

Siam G, Moussa H (2003) Food security in Egypt under economic liberalization policies and WTO agreement, International Conference Agricultural policy reform and the WTO: where are we heading?, Capri (Italy), June 23-26, 2003

Warda A, Michelsen A (2002) The economic value of water in agriculture: concepts and policy applications. Water Policy 4(2002):423-446

Yokwe S (2005) Investigation of the economics of water as used by smallholder irrigation farmers in South Africa, Department of Agricultural Economics, Extension \& Rural Development, Faculty of Natural and Agricultural Sciences, University of Pretoria 